\title{
Fish feeding and dynamics of soft-sediment mollusc populations in a coral reef lagoon
}

\author{
G. P. Jones*, D. J. Ferrell**, P. F. Sale ${ }^{* * *}$ \\ School of Biological Sciences, University of Sydney, Sydney 2006, N.S.W., Australia
}

\begin{abstract}
Large coral reef fish were experimentally excluded from enclosed plots for 2 yr to examine their effect on the dynamics of soft sediment mollusc populations from areas in One Tree lagoon (Great Barrier Reef). Three teleost fish which feed on benthic molluscs, Lethrinus nebulosus, Diagramma pictum and Pseudocaranx dentex, were common in the vicinity of the cages. Surveys of feeding scars in the sand indicated similar use of cage control and open control plots and effective exclusion by cages. The densities of 10 common species of prey were variable between locations and among times. Only 2 species exhibited an effect attributable to feeding by fish, and this was at one location only. The effect size was small relative to the spatial and temporal variation in numbers. The power of the test was sufficient to detect effects of fish on most species, had they occurred. A number of the molluscs exhibited annual cycles in abundance, with summer peaks due to an influx of juveniles but almost total loss of this cohort in winter. There was no evidence that predation altered the size-structure of these populations. While predation by fish is clearly intense, it does not have significant effects on the demography of these molluscs. The results cast doubt on the generality of the claim that predation is an important structuring agent in tropical communities.
\end{abstract}

\section{INTRODUCTION}

Coral reefs are surrounded by and frequently enclose expansive areas of soft sediments which are rich in invertebrates (Taylor 1971, Birtles \& Arnold 1983, Jones 1984, St. John et al. 1989). Our knowledge of the basic patterns of species composition and their distributions is limited (St. John et al. 1989, Jones et al. 1990). The dynamics of populations living in these sediments and the processes affecting these populations are poorly understood, yet these areas adjacent to coral reefs may be an important component of the reef system itself (Hatcher et al. 1989, Parrish 1989). A variety of reef-associated fishes, particularly large teleosts (families Haemulidae, Lethrinidae, Carangidae) and elasmobranchs (Dasyatididae, Mylio-

Present addresses:

- Department of Marine Biology, James Cook University, Townsville, 4811 Queensland, Australia

- Fisheries Research Institute, PO Box 21, Cronulla, N.S.W 2230, Australia

-. Department of Zoology and Center for Marine Biology University of New Hampshire, Durham, New Hampshire 03824, USA batididae), derive their energy resources from these soft sediments. The abundance of these groups on coral reefs may be more dependent upon the surrounding sediments than the reef itself. An understanding of the interactions between these 2 systems requires more information on the impact of fish feeding, firstly on the soft-sediment assemblages, and ultimately, on the coral reef system itself.

It has been argued that the impact of predation by fishes on benthic marine communities may be higher in tropical than in temperate regions (Bakus 1969, 1981, 1983, Vermeij \& Veil 1978, Bertness 1981, Gaines \& Lubchenco 1982, Lubchenco et al. 1984), despite the fact that to date, most of the experimental work on predation has been done in temperate waters (Choat 1982, Sih et al. 1985) and predation is an integral part of the ecological models developed for these cooler, lower-diversity systems (e.g. Menge \& Sutherland 1976). There is some evidence that fish do affect the distribution of corals (Neudecker 1977, 1979, Wellington 1982, Fitz et al. 1983), other sessile invertebrates (Bakus 1964, Day 1977, 1985, Lubchenco et al. 1984) and mobile invertebrates on the reef (Bertness 1981, Wolf et al. 1983, Reaka 1985, McClanahan \& Muthiga 
1989; see Jones et al. 1991 for review). The quality of this information varies, but assuming there are predation effects, there is no reason to believe they are any larger than for comparable temperate assemblages.

Predation is thought to play a key role in structuring soft-sediment invertebrate communities in temperate waters (Reise 1977, Peterson 1979, Sih et al. 1985; reviewed by Wilson 1991), although this conclusion is by no means universal (e.g. Berge \& Valderhaug 1983 , Thrush 1986). By comparison, predation in the softsediment or seagrass communities adjacent to coral reefs have received less attention (Alheit 1981, Alheit \& Scheibel 1982, Keller 1983, Jones et al. 1988, St. John et al, 1989). The data presented in these papers are inconclusive as to whether or not fish are important in these systems (Jones et al. 1991).

The aim of this study was to assess the contribution of fish feeding to natural variation in mollusc numbers and population structure in One Tree Lagoon, at the southern end of the Great Barrier Reef. The soft-sediment communities within this lagoon contain a rich and abundanl faund of molluscs (Jones et ai. 1990). These are preyed upon by a number of large, wideranging fishes such as Lethrinus nebulosus and Diagramma pictum (Jones et al. 1991).

A pilot experimental exclusion of fish was carried out in a previous study, at a single location near the perimeter of the lagoon, to assess the potential of this technique for examining the role of predation (Jones et al. 1988). Impacts of fish predation/disturbance were suggested but could not be distinguished from habitat selection by mobile prey. The latter could have occurred in response to changes in sediment composition inside full exclusion fences, which were quantified over the course of the experiment.

In designing this experiment, attention was given to the descriptive information already collected on mollusc abundances and fish feeding pressure and lessons learnt from the pilot experiment. These considerations included: (1) Given the patchy nature of teleost feeding, it was essential to carry out the same manipulations at a number of locations, to assess the generality of any observed effects. (2) The pilot experiment suggested that mollusc numbers fluctuate annually, and treatment effects may not be apparent for at least a year. Two years was considered ample time to detect any substantial effect of predation. (3) Given the possible mobility of the infauna, exclusion cages needed to be as large as possible. (4) The mesh used on the exclusion cage should be as large as possible to minimize effects on sediments, while still excluding the fish to be tested. (5) The effectiveness of the predator exclusion apparatus needed to be monitored (does it keep fish out?), as well as the relative use of cage control and open control sites (do cage controls keep fish out?). This was assessed by monitoring teleost feeding scars made in all plots of all treatments throughout the study.

\section{METHODS}

This study was carried out between May 1986 and May 1988 in the lagoon of One Tree Reef, near the southern limit of the Great Barrier Reef $\left(23^{\circ} 30^{\prime} \mathrm{S}\right.$, $152^{\circ} 06^{\prime} \mathrm{E}$ ). The $10 \mathrm{~km}^{2}$ lagoon primarily consists of carbonate soft sediments separated by reticulated reef structures and isolated patch reefs. Temporal patterns in the abundance and structure of mollusc populations, and the effects of fish predators, were monitored in a zone of deeper water near the perimeter of the lagoon (see Jones et al. 1990). This was the region of greatest mollusc diversity and highest fish feeding pressure on a lagoon-wide scale (Jones et al. 1990, 1991). These studies had also shown mollusc numbers and fish feeding intensity to vary among locations within this zone. In view of this we examined temporal patterns and predation effects at 3 different, randomly selected, locations: South, Shark Alley and North.

At each of the 3 locations, there were six $25 \mathrm{~m}^{2}$ plots, 2 of which were randomly allocated to each of the 3 treatments - full exclusion cage ('full cage'), cage control and open control. Cages to exclude the large teleost fishes were $5 \mathrm{~m}$ on each side and $1.4 \mathrm{~m}$ high to allow easy access to divers for sampling. The cages were constructed of an extruded plastic square mesh $(12 \times 12 \mathrm{~cm}$ and $1.5 \mathrm{~mm}$ thick). They effectively excluded rays and the 3 species of large teleosts commonly observed to feed over large, open expanses of sand (Lethrinus nebulosus, Diagramma pictum and Pseudocaranx dentex). Small carnivores such as most labrids were not excluded but were only observed feeding adjacent to reefs. The cages were framed with $2.1 \mathrm{~m}$ steel fencing posts driven into the sand and laced together with rope around their tops. The structure was made taut with guy-ropes at the corners. Skirts of caging mesh $30 \mathrm{~cm}$ wide were buried in the sand at the bottom of the cages and anchored with steel pegs. The control structures for the cages were made in an identical fashion except that the walls only covered half of the $5 \mathrm{~m}$ sides, allowing access to fishes.

The cages were cleaned and any holes repaired after sampling at each period. The large mesh and small diameter of the mesh material meant that fouling of the cage material was only a slight problem and algae could be removed easily with brooms. The mesh gradually accumulated small oysters and other encrusting organisms and was replaced on all cages after the first year. Substantial holes $(30$ to $100 \mathrm{~cm})$ were 
infrequently found in some cages, possibly caused by sharks or turtles.

All treatments were sampled during May 1986, just after the cages were constructed and on 6 subsequent occasions: August and November 1986, February, July and December 1987 and May 1988. Methods used to sample the abundances of molluscs have been fully described in Jones et al. (1990) and are briefly outlined below. All $25 \mathrm{~m}^{2}$ plots were sampled with 4 randomly placed $0.1 \mathrm{~m}^{2}$ circular cores whose contents were extracted to $5 \mathrm{~cm}$ depth with a diver-operated airlift suction apparatus. The airlifted samples were collected into $1 \mathrm{~mm}$ mesh bags which were immersed directly into 3 to $5 \%$ formaldehyde solution for fixation. The fixative contained a vital stain, Biebrich scarlet, to aid in sorting. All molluscs were extracted from the sediment, identified to species level and counted. A checklist of most of the molluscan fauna from the present sampling programme appeared in Jones et al. (1990).

This study concentrated on 10 abundant species known to be consumed by large predatory fish (Jones et al. 1991). These were the gastropods Umbonium guamensis (Quoy \& Gaimard, 1834), Pupa nitidula (Lamarck, 1916), Atys cylindricus (Helbing 1779), and the bivalves Exotica rhomboides (Quoy \& Gaimard, 1834), Exotica cf. virgulata (Hanley, 1845), Fragum sp., Solemya sp., Tellina of. myaformis Sowerby, 1868, Tellina obtusalis Destayes, 1845 and Tellina robusta (Hanley, 1844).

The effects of predators on spatial and temporal patterns in the structure of mollusc populations were analysed by examining size-frequency distributions. The sizes of all molluscs were measured using a dissecting microscope coupled to a high resolution video camera and monitor. Measurements were made using a video position analyser (Four-A Company Ltd., Tokyo, Japan) which superimposed an $x-y$ axis and cursor on the video image, and data were compiled on a personal computer.

Differences in fish feeding pressure among locations, times and treatments were estimated by surveying the scars left in the sediment by feeding episodes (see Jones et al. 1991). Actively feeding individuals of Lethrinus nebulosus, Diagramma pictum and Pseudocaranx dentex were followed in order to characterise the appearance of the feeding scars in the sediment. All 3 species fed by biting into loose sediment, taking a large mouthful and sorting the sediment in the mouth. The depressions left after each bite were uniformly round with gently sloping sides ending in a flat bottom covered with highly sorted, fine sediment. The scars made by the 3 fish species could not be distinguished from each other but were easily differentiated from other irregularities in the surface of the sediment. Scars in caged, partially caged and open plots were sampled at the last 4 sampling dates using six $1 \mathrm{~m}^{2}$ quadrats at each sampling time. Feeding scars in cages were associated with holes in cages, so scars were counted prior to sampling or repair of the cages; these counts are likely to indicate the highest level of fish feeding inside cages. Cages that remained intact between sampling occasions had no feeding scars, nor were feeding scars observed inside cages for at least a month after repair.

Densities of feeding scars provide a relative rather than an absolute measure of fish feeding intensity. The latter required an estimate of the number of feeding bites per unit area made per unit time. To calculate this we needed an estimate of the longevity of feeding scars. The rate with which the feeding scars filled in and became unrecognisable was established for each location using a small coring device (a section of PVC pipe $40 \mathrm{~mm}$ in diameter) to make artificial feeding scars. The artificial scars were indistinguishable from real ones, but allowed precise knowledge of their time of formation. At each caging location, 2 plots containing 4 blocks of 10 artificial scars were created in the morning. The proportion of scars remaining distinguishable in each block of 10 was checked approximately every $3 \mathrm{~h}$. The numbers of artificial scars filling in over time was approximately linear and linear regression was used to estimate the time at which half the artificial bites had become unrecognisable for each set of 10 artificial scars. This procedure gave an estimate of the mean life-span of a feeding scar, and allowed the observed values of scars per $\mathrm{m}^{2}$ to be standardised to scars $\mathrm{m}^{-2} \mathrm{~h}^{-1}$. This information, combined with an estimate of the average volume of each fish bite, was then used to estimate the average time it took for all the surface sediment to be turned over by fish.

A sediment grain-size analysis was done at all sampling dates to assess the stability of the sediments and any effects attributable to the caging apparatus. Two $50 \mathrm{ml}$ jars of sediment were collected from random locations within all plots, and were processed by a method suggested by Folk (1974) for carbonate sediments. The samples, which were stored in ethanol, were first dried to constant weight (ca $7 \mathrm{~d}$ at $60^{\circ} \mathrm{C}$ ) and then wet-sieved through a $63 \mu \mathrm{m}$ screen. The retained sand fraction was dried, re-weighed and separated into standard $1 \phi$ fractions by shaking for $10 \mathrm{~min}$ on a geological sieve shaker. Each fraction was weighed separately to produce sediment grain size-frequency distributions

A mixed model analysis of variance was used to test for the numerical effects of location (a random factor), time and treatment (fixed factors), and their interactions, on each of the common mollusc species. Posthoc pooling was done wherever $\mathrm{p}>0.25$ for effects of interactions, to increase the power of the test for de- 
tecting treatment effects (Winer 1971). Where treatments were not significant, power analyses (Cohen 1988) were used to determine what magnitude of treatment effects would likely have been detected in this size experiment.

\section{RESULTS}

\section{Abundance}

The abundance of all mollusc species differed among location and/or times (Fig. 1). For all but 2 species, there were inconsistent differences among times ('Location $\times$ Time' interaction; see Table 1a), indicating significant, location-specific changes over the 2 yr period. Several taxa experienced peaks of abundance in summer (December to February): Atys cylindricus, Umbonium guamensis, Exotica rhomboides, Fragum sp., Solemya sp., and Tellina myaformis. Pupa nitidula and E. virgulata exhibited a tendency to be higher in the winter months. There were no obvious seasonal patterns for $T$. obtusalis and $T$. robusta, with patterns of temporal change in abundance differing among locations.
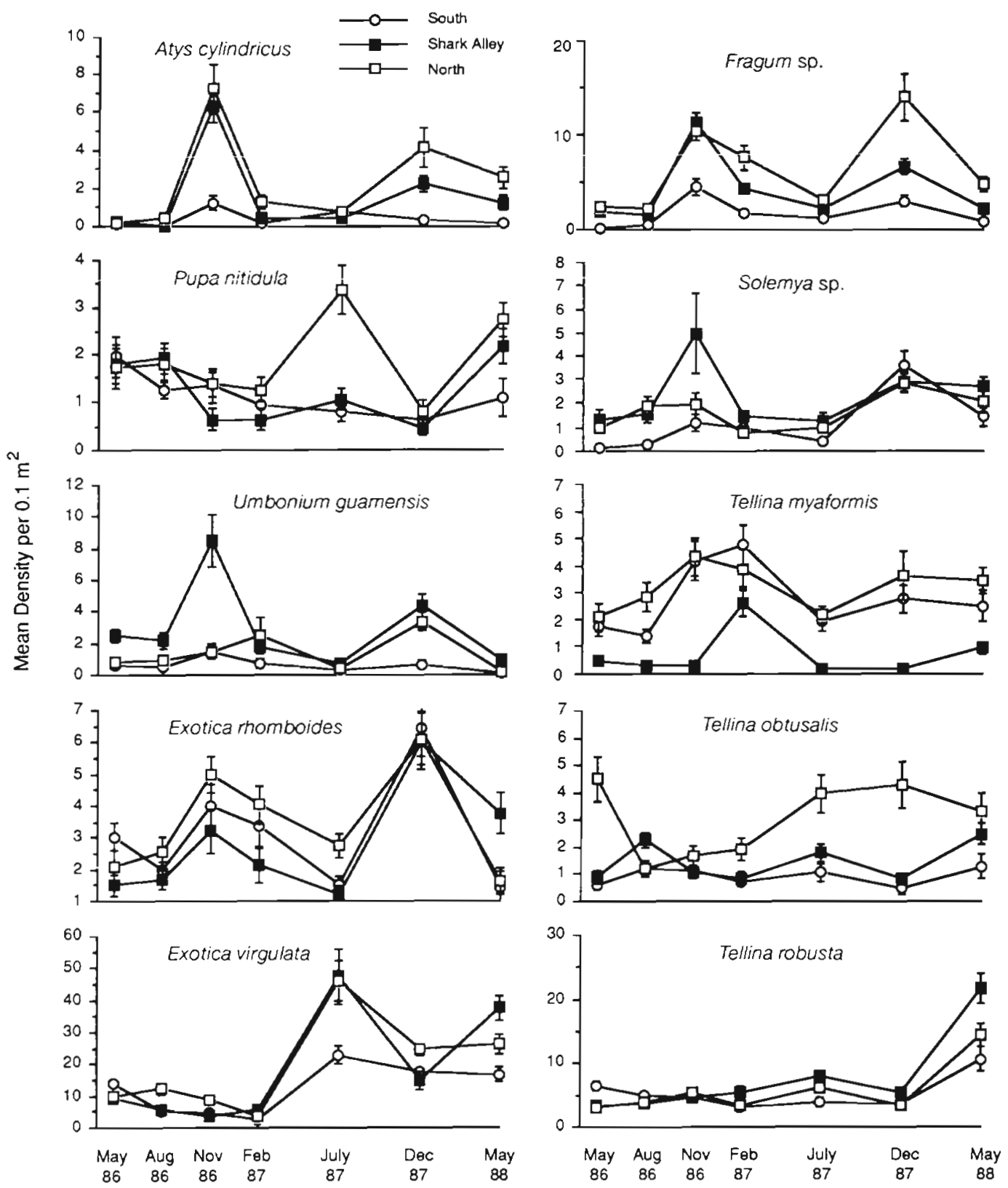

Fig. 1. Temporal changes in mean densities of the 10 common mollusc species at the 3 sampling locations - North, Shark Alley and South, from 1986 to 1988. Error bars = standard errors. All treatments for each location pooled 
Table 1. (a) Analysis of variance results for the effects of time, location, treatment and plot on the densities of 10 mollusc species. Homogeneity of variances was achieved with $\ln (x+1)$ transformation $(\cdot$ significant at 0.05 level; " significant at 0.01 level; ns: not significant). (b) Percent variance explained by each factor and their interactions. Based on raw data. Species: A. C., Atys Cylindricus; E. r., Exotica rhomboides; E. v., Exotica virgulata; F. sp., Fragum sp.; P. n., Pupa nitidula; S. sp., Solemya sp.; T. m., Tellina myaformis; T. o., Tellina obtusalis; T. r., Tellina robusta; U. g., Umbonium guamensis

\begin{tabular}{|c|c|c|c|c|c|c|c|c|c|c|c|}
\hline & & A. $C$. & E. $r$. & E. V. & F. sp. & P. $n$. & S. sp. & $T m$ & T. $O$ & T. $r$ & $U \cdot g$ \\
\hline \multicolumn{12}{|c|}{ (a) ANOVA results } \\
\hline Time, A & 6 & $7.4^{\cdots}$ & $4.9 \cdots$ & $14.9^{\circ}$ & $39.5^{\cdots}$ & $2.8^{n s}$ & $7.8^{\circ}$ & $4.7^{\circ}$ & $0.5^{\mathrm{ns}}$ & $4.7^{\circ}$ & $4.1^{\circ}$ \\
\hline Location, B & 2 & $40.1^{\circ}$ & $0.8^{\mathrm{ns}}$ & $10.8^{\bullet}$ & $21.7^{\circ}$ & $5.1^{\bullet}$ & $4.5^{\circ}$ & $26.7^{\cdots}$ & $4.0^{\circ}$ & $0.5^{\mathrm{ns}}$ & $9.2^{\cdots}$ \\
\hline Treatment, C & 2 & $14.2^{\circ}$ & $0.6^{\mathrm{ns}}$ & $4.0^{\mathrm{ns}}$ & $2.5^{1 \mathrm{~s}}$ & $1.7^{n s}$ & $16.9^{\circ}$ & $0.1^{\mathrm{ns}}$ & $0.0^{\mathrm{ns}}$ & $0.7^{\mathrm{ns}}$ & $0.4^{\mathrm{ns}}$ \\
\hline Plot, D (BC) & 9 & $1.8^{\mathrm{ns}}$ & $6.5 \cdots$ & $1.2^{\mathrm{ns}}$ & $5.5^{\cdots}$ & $2.4^{n s}$ & $4.6^{*}$ & $3.5 *$ & $14.8^{*}$ & $11.4^{*}$ & $7.8^{*}$ \\
\hline$A \times B$ & 12 & $4.1^{\cdots}$ & $3.4^{\cdots}$ & $4.0^{\cdots}$ & $1.2^{\mathrm{ns}}$ & $2.4^{\circ}$ & $1.8^{\mathrm{ns}}$ & $3.0^{\circ}$ & $5.4^{\cdots}$ & $4.8^{\cdots}$ & $3.8^{\circ}$ \\
\hline $\mathrm{A} \times \mathrm{C}$ & 12 & $2.8^{\circ}$ & $1.1^{\mathrm{ns}}$ & $1.1^{\mathrm{ns}}$ & $0.8^{\mathrm{ns}}$ & $1.0^{\mathrm{ns}}$ & $2.6^{\circ}$ & $1.0^{\mathrm{ns}}$ & $1.2^{n s}$ & $2.1^{\mathrm{ns}}$ & $1.2^{\mathrm{ns}}$ \\
\hline$A \times D(B C)$ & 54 & $2.5^{\cdots}$ & $1.2^{\mathrm{ns}}$ & $2.1^{\cdots}$ & $1.3^{\mathrm{ns}}$ & $1.5^{\circ}$ & $1.4^{\circ}$ & $0.9^{n s}$ & $1.4^{\cdots}$ & $1.5^{\circ}$ & $1.6^{\circ}$ \\
\hline $\mathrm{B} \times \mathrm{C}$ & 4 & $2.2^{\mathrm{ns}}$ & $0.7^{\mathrm{ns}}$ & $5.6^{\circ}$ & $0.5^{\mathrm{ns}}$ & $0.9^{\mathrm{ns}}$ & $0.2^{\mathrm{ns}}$ & $2.8^{\mathrm{ns}}$ & $1.2^{\text {ns }}$ & $0.8^{\mathrm{ns}}$ & $0.4^{\mathrm{ns}}$ \\
\hline$A \times B \times C$ & 12 & $1.0^{\mathrm{ns}}$ & $0.7^{\mathrm{ns}}$ & $1.6^{\mathrm{ns}}$ & $1.1^{\mathrm{ns}}$ & $1.0^{\mathrm{ns}}$ & $0.6^{\mathrm{ns}}$ & $1.1^{\mathrm{ns}}$ & $1.4^{\mathrm{ns}}$ & $1.0^{\mathrm{ns}}$ & $0.8^{\mathrm{ns}}$ \\
\hline Residual & 378 & & & & & & & & & & \\
\hline \multicolumn{12}{|c|}{ (b) Variance explained (\%) } \\
\hline Time, A & & 22 & 20 & 33 & 24 & 5 & 8 & 7 & 0 & 33 & 7 \\
\hline Location, B & & 9 & 0 & 3 & 15 & 5 & 2 & 20 & 13 & 1 & 11 \\
\hline Treatment, $\mathrm{C}$ & & 6 & 0 & 6 & 1 & 1 & 4 & 0 & 0 & 0 & 0 \\
\hline Plot, D (BC) & & 0 & 10 & 1 & 3 & 2 & 9 & 5 & 21 & 11 & 8 \\
\hline$A \times B$ & & 11 & 3 & 7 & 9 & 7 & 3 & 2 & 11 & 10 & 15 \\
\hline $\mathrm{A} \times \mathrm{C}$ & & 6 & 1 & 10 & 0 & 0 & 3 & 0 & 0 & 5 & 1 \\
\hline$A \times D(B C)$ & & 11 & 7 & 12 & 4 & 14 & 8 & 0 & 5 & 3 & 7 \\
\hline $\mathrm{B} \times \mathrm{C}$ & & 4 & 0 & 4 & 0 & 0 & 0 & 4 & 0 & 0 & 0 \\
\hline $\mathrm{A} \times \mathrm{B} \times \mathrm{C}$ & & 7 & 0 & 5 & 7 & 0 & 0 & 1 & 12 & 3 & 0 \\
\hline Residual & & 25 & 59 & 20 & 37 & 65 & 63 & 61 & 39 & 36 & 52 \\
\hline
\end{tabular}

Of the 3 sites, Shark Alley and North tended to support higher densities of molluscs than South. This trend was most apparent for Atys cylindricus, Umbonium guamensis, Fragum sp., and Tellina obtusalis (Fig. 1). By contrast, T. myaformis was consistently lowest in abundance at Shark Alley.

There were no consistent or dramatic effects of the caging treatments of the abundance of molluscs after cage construction, either at some locations or some times (Table 1a). Atys cylindricus exhibited a 'Treatment $\times$ Time' interaction, which appeared to be due to a difference among treatments detected during the summer peaks in abundance (Fig. 2). At these times, numbers tended to be higher in full cages. However, numbers in cage controls were occasionally higher than in open areas, suggesting some cage artifacts were involved, e.g. during November 1986 at North. The absence of summer peaks in abundance in completely open areas suggests that recruits were preyed upon.

Another species for which a treatment effect was detected was Exotica virgulata (Fig. 3), for which the analysis exposed a 'Treatment $\times$ Location' interaction (Table 1a). Inspection of the graph strongly suggests that this was due to an effect of fish predation at Shark Alley, which developed during the last year of the study. Densities of this small bivalve inside cages were almost twice the density they were in areas exposed to fish predation. The densities of $E$. virgulata were higher at all locations following a large increase in their numbers recorded in July 1987. The treatment effects at North and South both appeared to be due to cage artifacts (Fig. 3). A treatment effect was observed for the bivalve Solemya sp. (Table 1a, Fig. 4). At Shark Alley, full cages supported consistently greater numbers than the controls over the last 3 sampling dates. At North and South, both full cages and cage controls tended to increase relative to open areas, suggesting a cage effect contributed to the pattern.

Two mollusc species dominant in the stomachs of Lethrinus nebulosus and Diagramma pictum, the gastropod Umbonium guamensis, and the bivalve Fragum sp., showed no sign of significant effects of the treatments on their abundances (Table 1a, Figs. 5 \& 6). Both species' abundances changed seasonally, with highest values in the summer months.

In general, although there were some apparent effects of predators and/or cages, these accounted for little of the overall variation in numbers (Table $1 \mathrm{~b}$ ). 'Treatments' (main effects), 'Treatment $\times$ Time', and 'Treatment $\times$ Location' interactions never accounted for more than $10 \%$ of the overall variation among means and were usually much less. There was con- 


\section{Atys cylindricus}
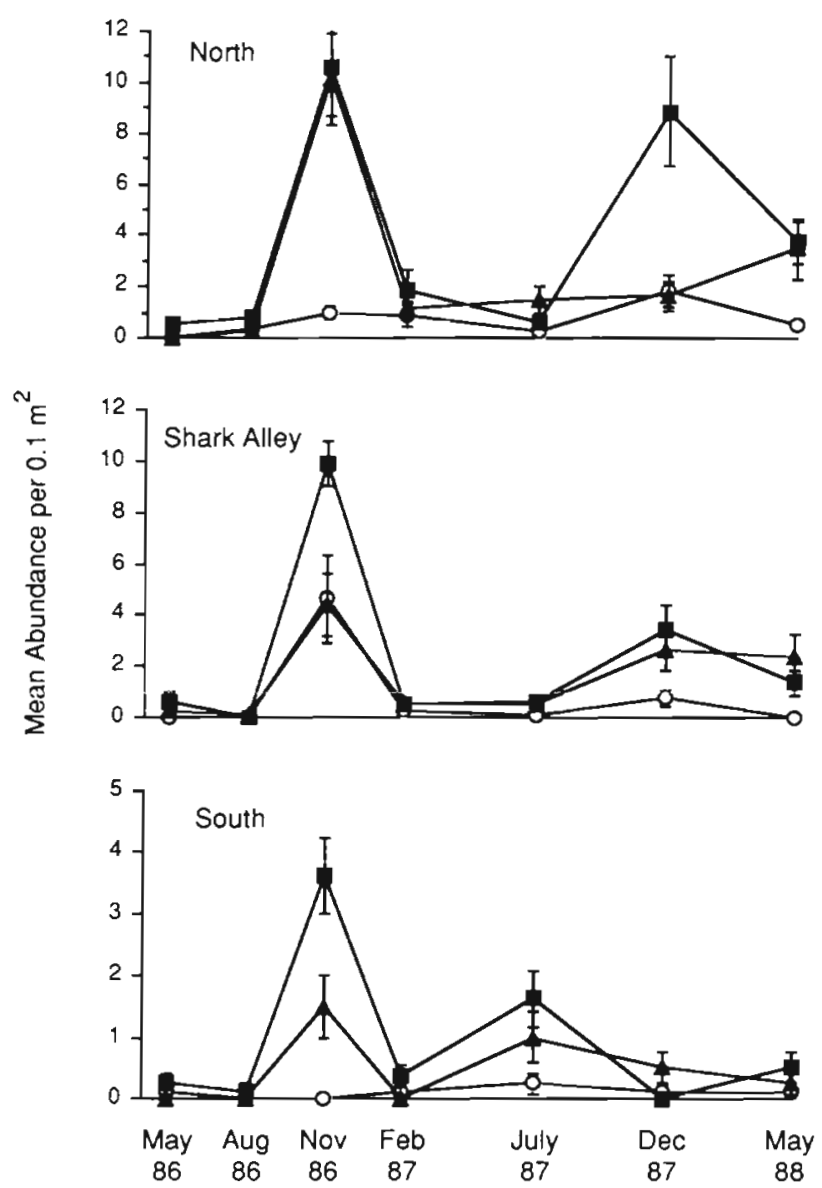

Fig. 2. Atys cylindricus. Effects of cage treatment (- - full cage, $\longrightarrow$ cage control, $\bigcirc-0$ open control) on temporal changes in mean molluscs density (per $0.1 \mathrm{~m}^{2}$ ) at the $3 \mathrm{sam}$ pling locations, 1986 to 1988 . Error bars = standard errors

siderably more spatial and temporal variation in numbers occurring than could be attributed to the caging manipulation.

'Location' accounted for up to $20 \%$ of the variation, and 'Time' up to $33 \%$. Also of considerable importance was the local-scale variation among 'Plots'. which explained up to $21 \%$ of the variation.

There was obviously a certain probability that we did not detect significant effects of predators on 6 of the species due to type II error (i.e. failure to reject a false null hypothesis). To examine this possibility, we calculated the amount abundances in full cages would have needed to differ from the 2 control treatments (as a percentage of their mean) to have an $80 \%$ probability of detecting that difference. Departures of $10 \%$ in Umbonium guamensis, $25 \%$ in Pupa nitidula and Exotica rhomboides and $35 \%$ in Tellina myaformis, $T$. obtusalis and $T$. robusta from their control means would have been detected with at least $80 \%$ probability.

\section{E. virgulata}
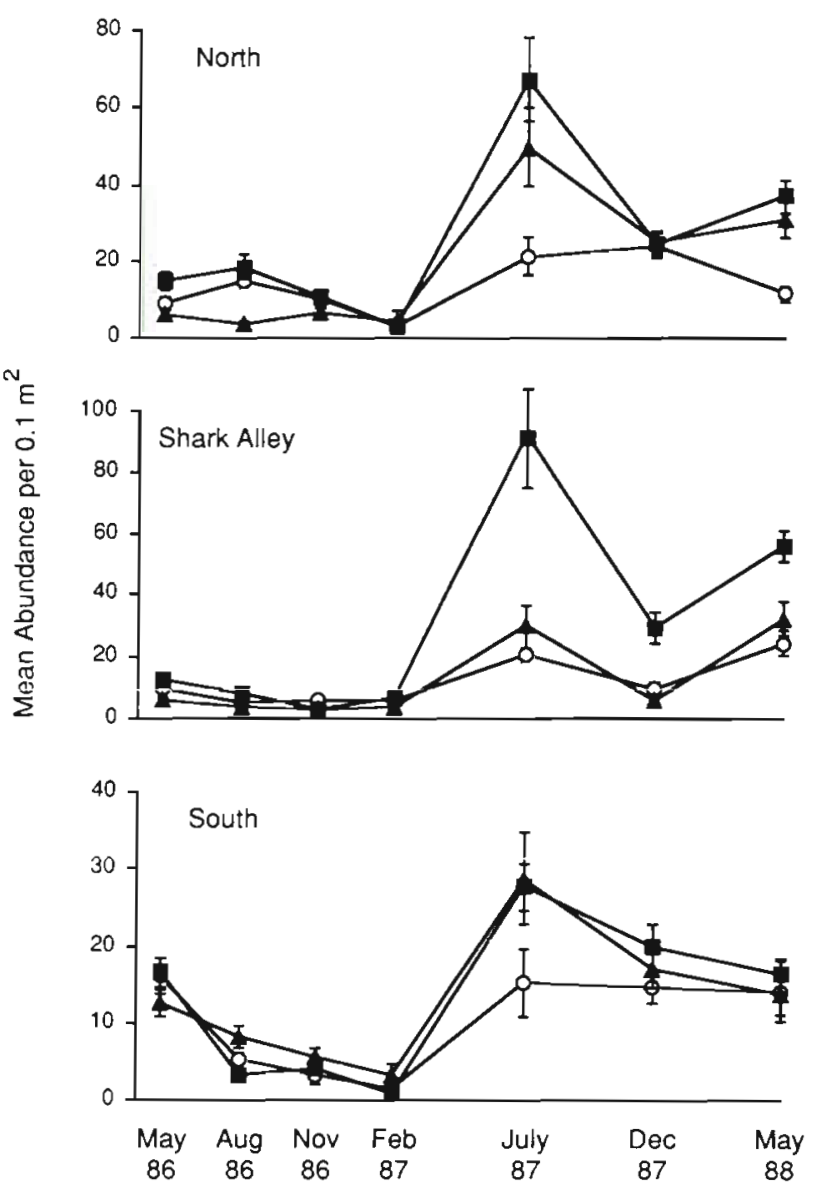

Fig. 3. Exotica cf. virgulata. Effects of cage treatment (full cage, $\longrightarrow$ cage control, $0-0$ open control) on temporal changes in mean mollusc density (per $\left.0.1 \mathrm{~m}^{2}\right)$ at the 3 sampling locations, 1986 to 1988 . Errors bars $=$ standard errors

\section{Population structure}

The changes in abundance which occurred over the 2 yr period were associated with changes in population structure, as measured by changes in sizefrequency distributions. Increases were normally associated with a massive influx of individuals in the smaller size classes (loosely termed recruits). The majority of the species exhibited summer peaks in recruitment, sometime between November and February [e.g. Umbonium guamensis (Fig. 7) and Fragum sp. [Fig. 8)]. For the swimming gastropod, $U$. guamensis, some juveniles were present during most of the year, but the greatest numerical inputs were recorded in November 1986 and December 1987 (Fig 7). These discrete cohorts grew rapidly until May but with substantial declines in abundance. They persisted through July and August, but abundances were lowest in late winter-spring, before the next recruitment period. Thus very few adults, if any, 

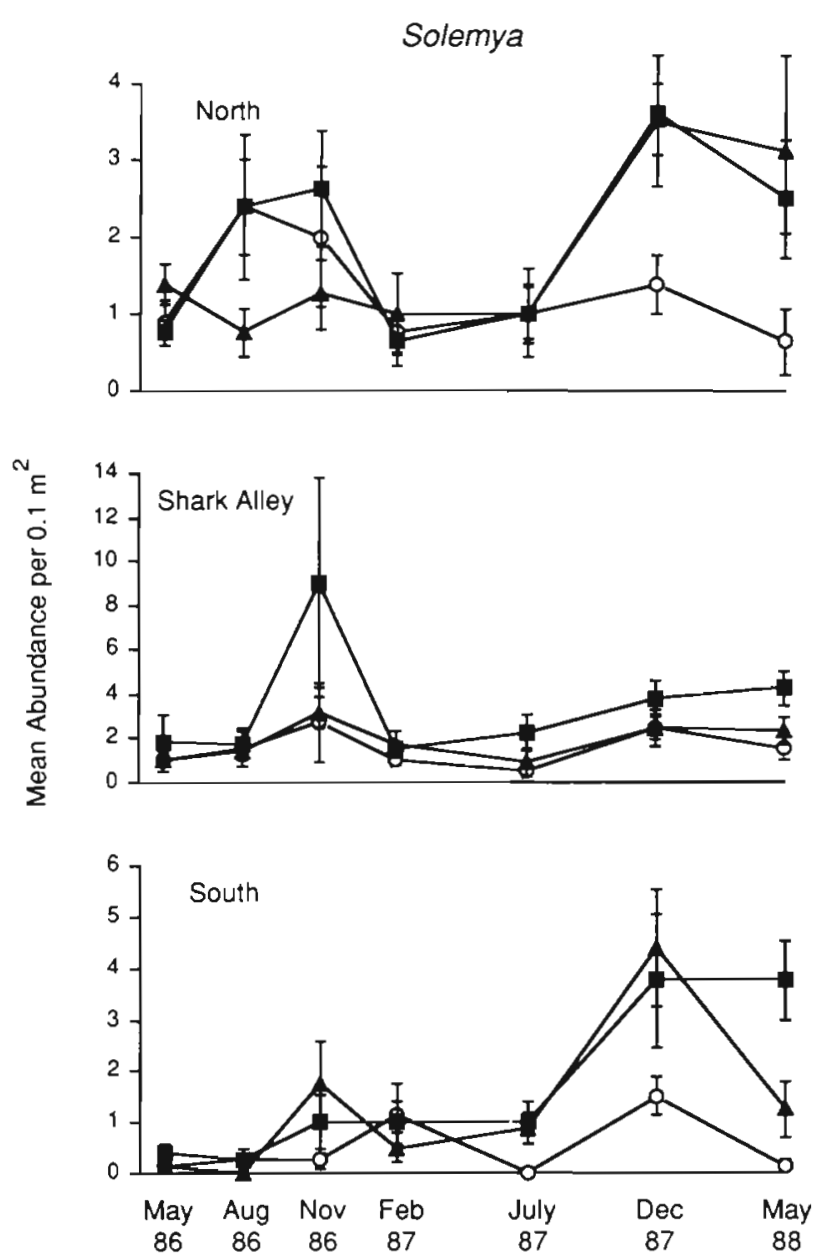

Fig. 4. Solemya sp. Effects of cage treatment (- full cage, $\leadsto$ cage control, 0 open control) on temporal changes in mean mollusc density (per $0.1 \mathrm{~m}^{2}$ ) at the 3 sampling locations, 1986 to 1988 . Errors bars = standard errors

appear to be present at the next recruitment, suggesting that for the majority of the population the species is annual.

The suggestion of an annual life cycle and a period of intense adult mortality in late winter applied to several other species, including the bivalve Fragum sp. (Fig. 8). Recruitment was clearly pulsed in November-December, and individuals appeared to grow rapidly until May, and persisted to July-August. After this the cohort essentially disappeared. Other species that exhibited a seasonal loss of the adult cohort were Pupa nitidula, Exotica cf. virgulata and Tellina myaformis. All appear to be annual.

The temporal changes in size-frequency distributions suggested that predation may have an impact on population on a seasonal basis. To examine this we compared size-frequency distributions for the 3 treatments (full cage, cage control, open control) separately for the summer and winter months. These are pre-
Umbonium guamensis
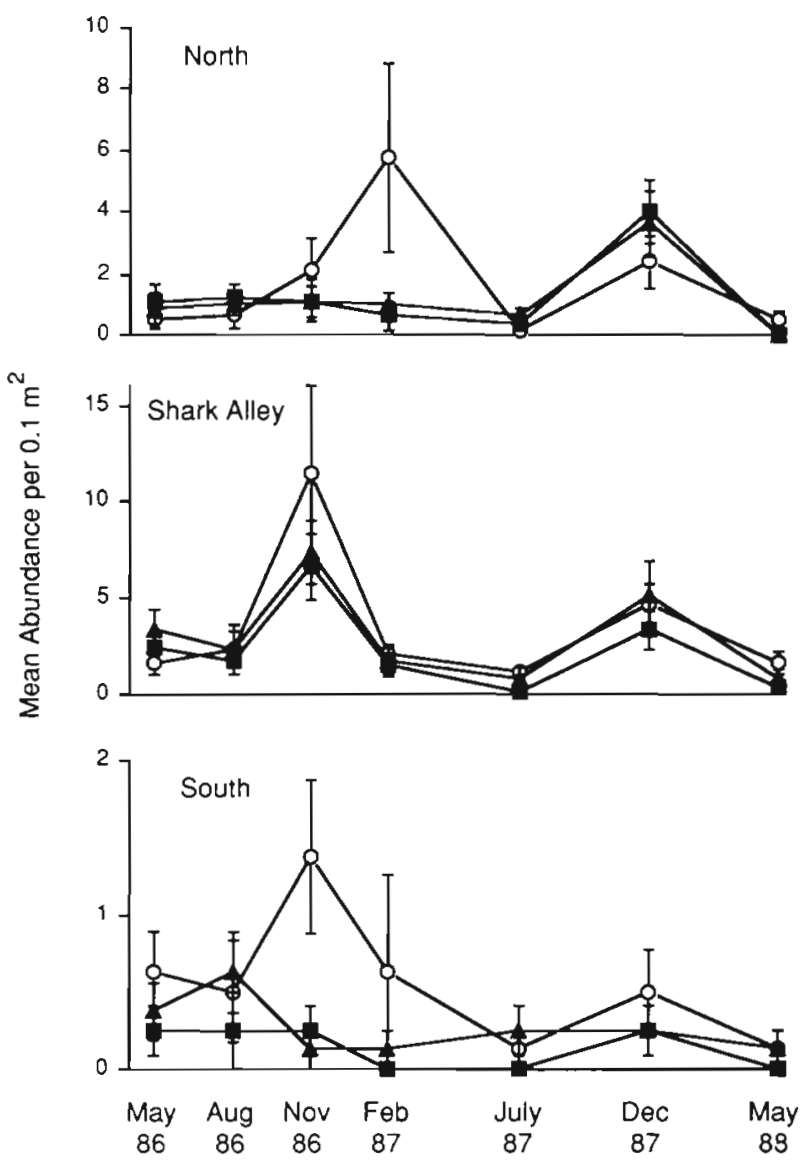

Fig. 5. Umbonium guamensis. Effects of cage treatment (full cage, a cage control, o- o open control) on temporal changes in mean mollusc density (per $0.1 \mathrm{~m}^{2}$ ) at the $3 \mathrm{sam}$ pling locations, 1986 to 1988 . Errors bars $=$ standard errors

sented for both the gastropod Umbonium guamensis (Fig. 9) and the bivalve Fragum sp. (Fig. 10), the most frequently consumed prey. Despite the massive differences in these pooled size frequencies between seasons, there was no obvious effect of the predator exclusion or the cage itself, either at Shark Alley or North, where these 2 species were most abundant.

\section{Feeding pressure and eifectiveness of predator exclusion}

Feeding pressure, as measured by the densities of teleost feeding scars outside cages, varied considerably among locations and times (Table 2, Fig. 11). Fish feeding appeared to be consistently higher at Shark Alley, compared to the other 2 locations. Patterns of temporal change in fish feeding pressure were not consistent from one location to the next (the 'Location $\times$ Time' interaction). 
Fragum sp.
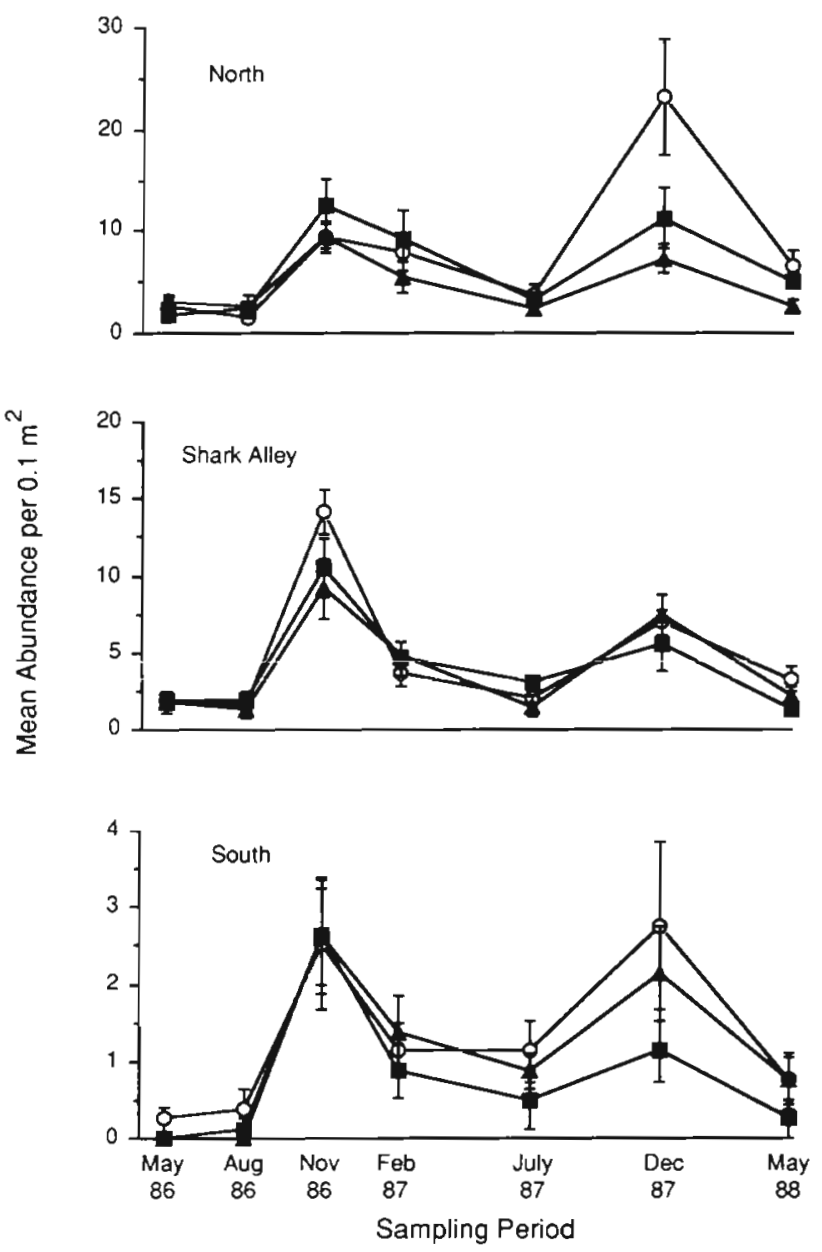

Fig. 6. Fragum sp. Effects of cage treatment ( $\square$ full cage, 4 cage control, $O-0$ open control) on temporal changes in mean mollusc density (per $0.1 \mathrm{~m}^{2}$ ) at the 3 sampling locations, 1986 to 1988 . Errors bars = standard errors

Full cages were not totally effective in excluding predators, as the caging material was occasionally torn between sampling trips. Prior to repairing these breaches, teleost feeding bites were observed within cages (Fig. 11). However, feeding scar densities differed significantly among 3 different treatments. Full cages had significantly lower feeding bite scar densities than the other 2 control treatments, which were not significantly different from each other (Table 2). Hence, cages certainly reduced fish feeding, and cage controls did not appear to modify fish feeding relative to open areas. Since fish feeding inside cages was eliminated for ca 1 mo following each repair, cages were more effective in excluding fish than Fig. 11 suggests. The worst cage-breaching occurred at North between the last 2 sampling dates. However, this did
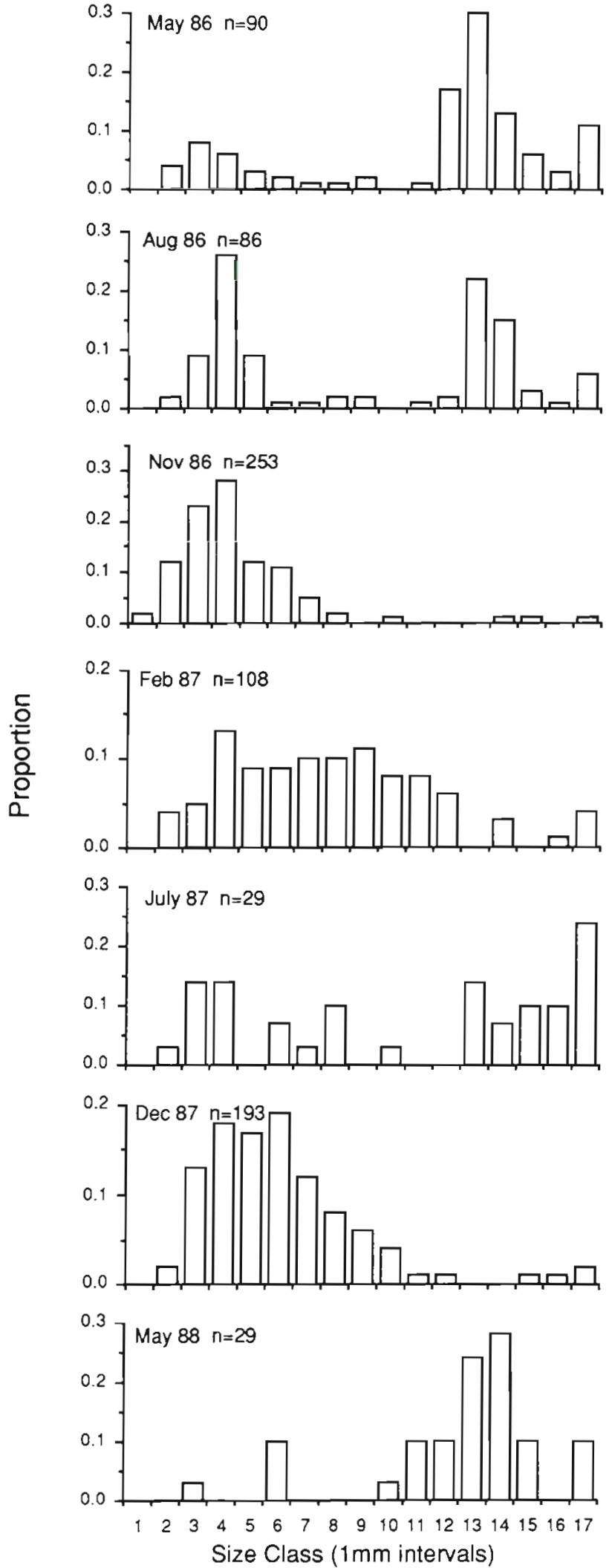

Fig. 7. Umbonium guamensis. Temporal changes in the sizefrequency distribution of molluscs for pooled locations and treatments, 1986 to $1988 . \mathrm{n}=$ sample size 


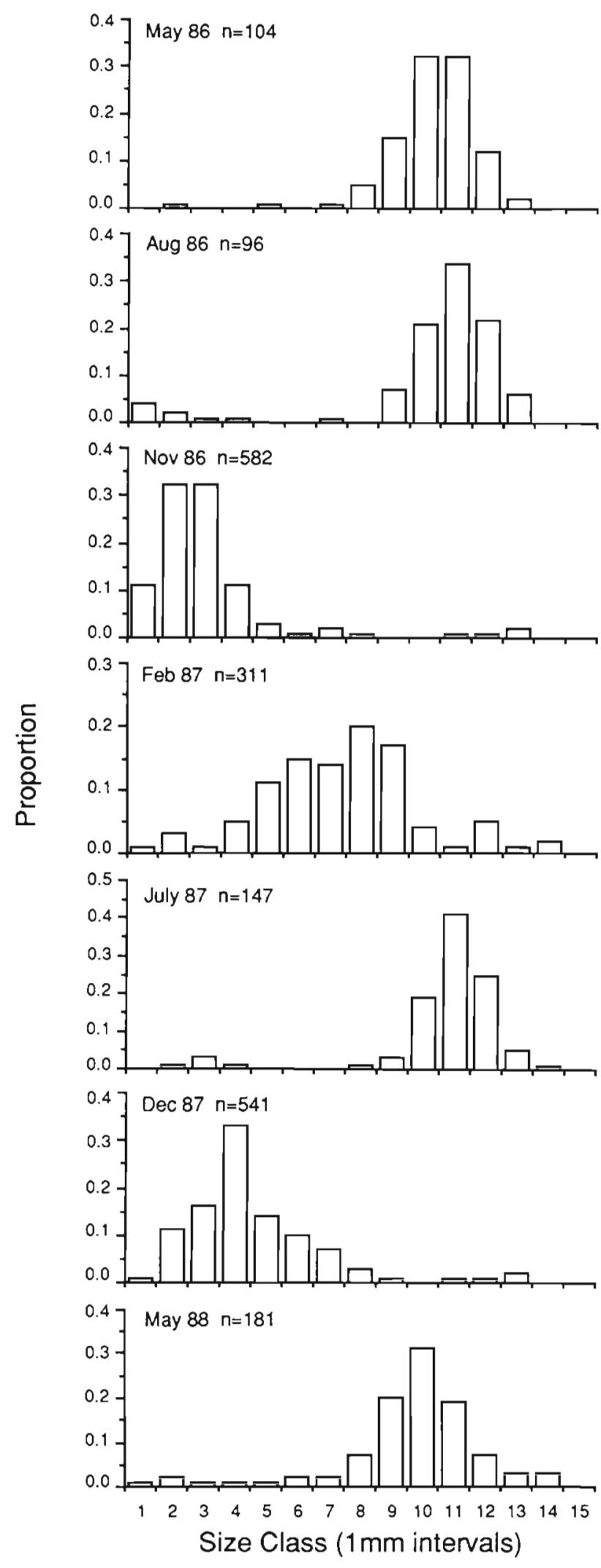

Fig. 8. Fragum sp. Temporal changes in the size-frequency distribution of molluscs for pooled locations and treatments, 1986 to 1988 . $\mathrm{n}=$ sample size not result in the breakdown of any effects of fish exclusion (Figs. 3 to 6) except perhaps for Atys cylindricus (Fig. 2)

The average time it took artificial feeding scars to disappear was similar for the 3 locations (Table 3). Therefore, bite densities were roughly proportional to bites $\mathrm{m}^{-2} \mathrm{~d}^{-1}$. This estimate was ca $4 \times$ higher at Shark Alley than the other 2 locations. Assuming that bites are made randomly in space (which may not be the case), the entire surface layer of the sediments at Shark Alley is being turned over by predators approximately every $300 \mathrm{~d}$. Estimates are considerably longer for the other 2 sites.

\section{Effects of cages on sediment composition}

The sediments were dominated by a sand fraction of intermediate grain size $(>125,<500 \mu \mathrm{m})$ (Fig. 12). All locations were fairly similar in this regard, although Shark Alley had slightly coarser sediments compared with the other 2 locations. The sediment composition was stable over the 2 yr study, as indicated by the comparisons of samples taken at the beginning of the study (May 1986), mid-way through the study (May 1987) and at the end (May 1988). The sediment grain sizefrequency distributions were almost identical for cage, cage control and open controls at all stages of the study.

\section{DISCUSSION}

The aims of this study were to describe patterns in the dynamics of mollusc populations in the sediments near the southern perimeter of One Tree lagoon, and determine the extent to which these patterns are influenced by predation by large fishes. That is, we were concerned not only with detecting significant effects, but with making some assessment of their biological importance to the prey populations. We examined 10 common species, all consumed by large fishes (Jones et al. 1991), and used a quantitative, predatorexclusion approach to measure the effects of predation, both on overall numbers and population structure.

Although the temporal pattern in abundance of each species was somewhat unique, seasonal patterns with summer peaks in numbers were common. These patterns occurred in the presence and absence of predation for most species at most locations. Some evidence of predator-induced effects on dynamics were evident for 2 species only (Exotica virgulata and Solemya sp.). For these, full cages supported higher numbers than cage controls and open controls toward 


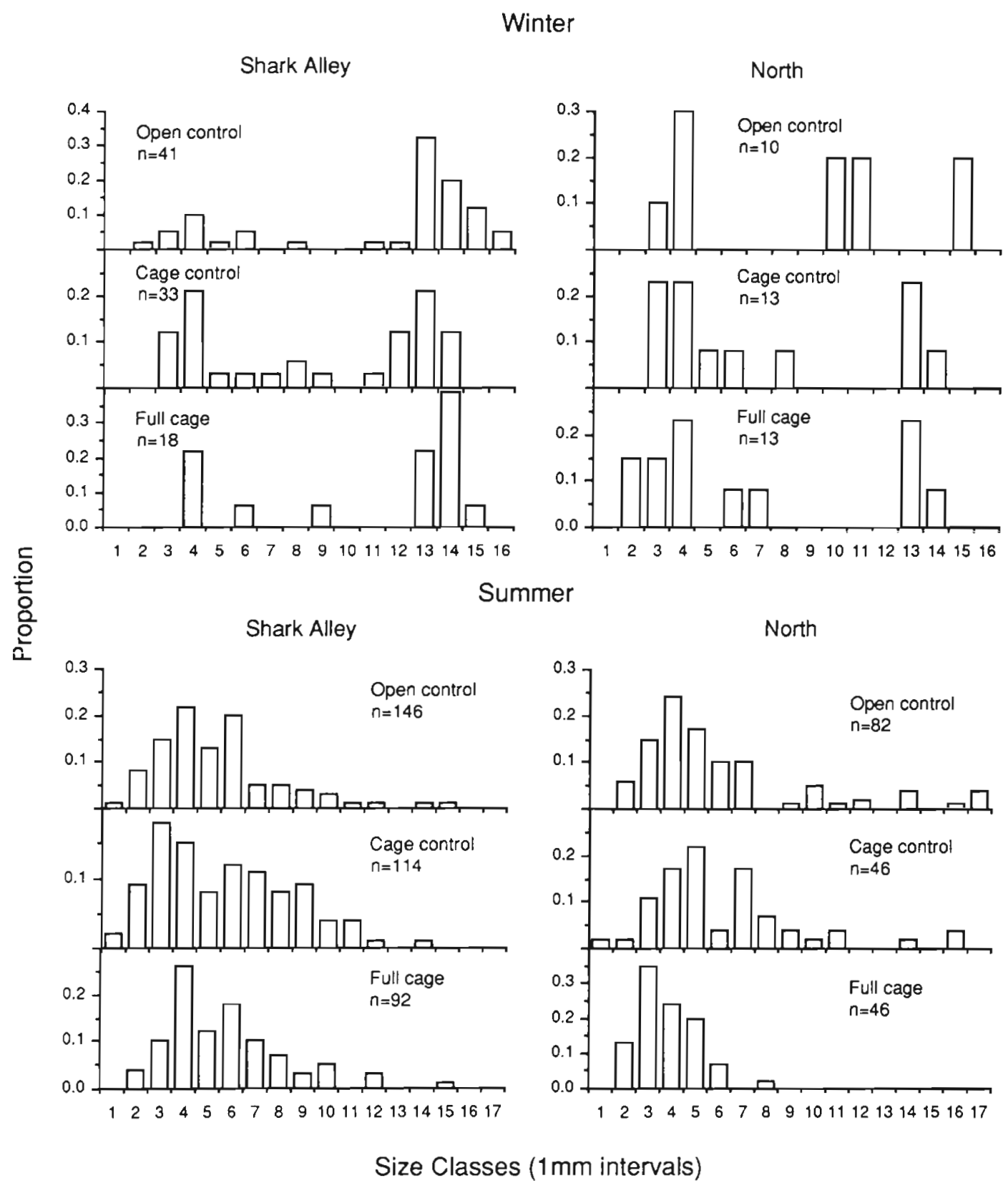

Fig. 9. Umbonium guamensis. Summer and winter differences in size-frequency distributions of molluscs in full cage, cage control and open control treatments at Shark Alley and North. (Note: Values were too small to plot size-frequency distributions for South. $n=$ sample size

the end of the experiment. Other treatment effects that occurred at some times were more likely to be due to cages rather than predators (e.g. Atys cylindricus and Tellina robusta). There was no general effect of predation on dynamics and no apparent seasonal change in fish feeding intensity (as measured by feeding scars) which could account for the winter decline in numbers.

The species affected do not correspond in any way to their proportional representation in the stomachs of either of the 2 key teleost predators, Lethrinus nebulosus or Diagramma pictum, in One Tree lagoon. $L$. nebulosus consumes mainly Fragum sp, and Umbonium guamensis and $D$. pictum prefers $U$. guamensis and Tellina robusta (Jones et al. 1991). Both Exotica rhomboides and Solemya sp. are consumed, but in low numerical proportions. Neither do the impacts correspond to the abundance of the prey species; Exotica virgulata was the most abundant mollusc and Solemya sp. was one of the least abundant. 

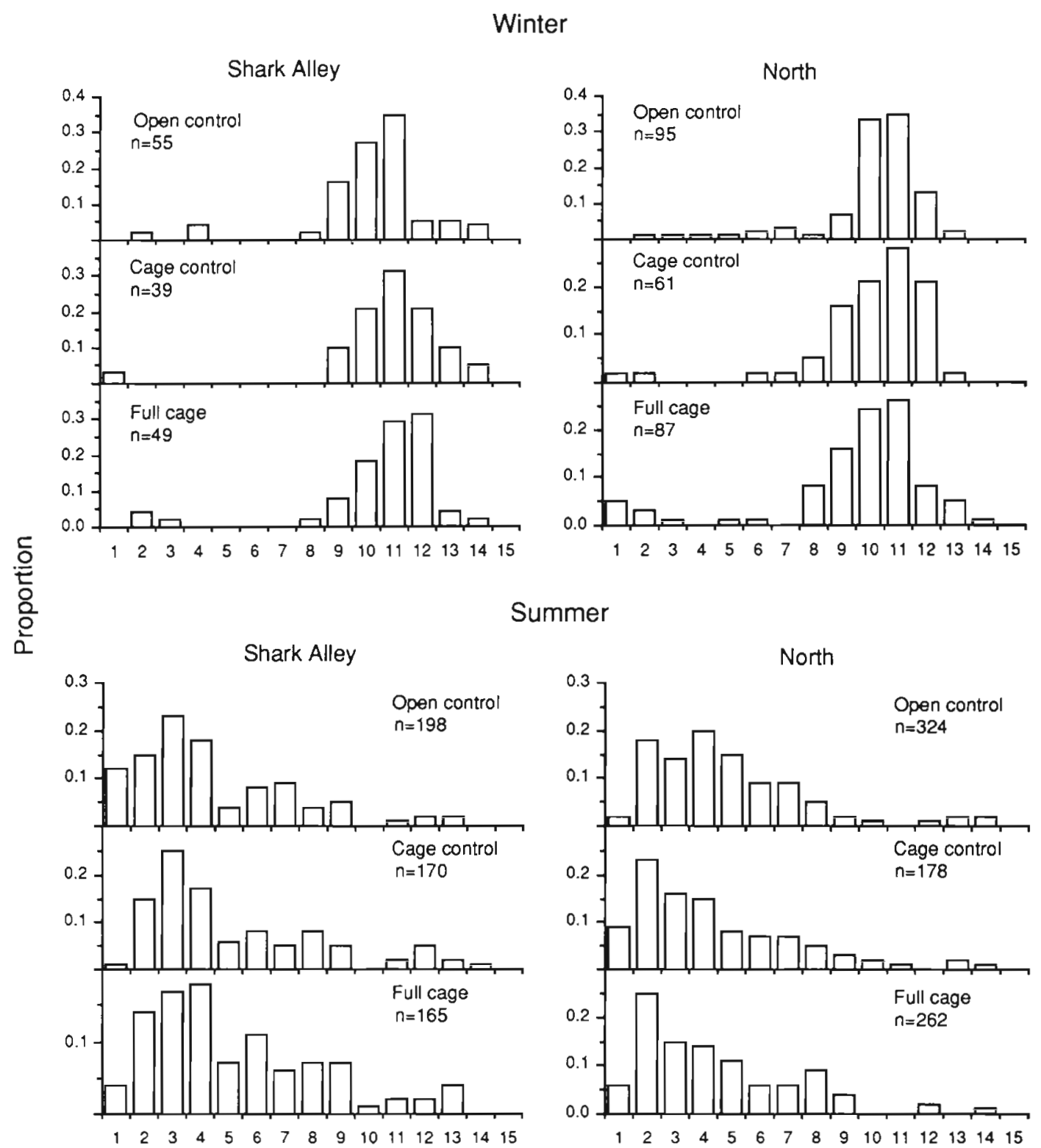

Size Classes (1 $\mathrm{mm}$ intervals)

Fig. 10. Fragum sp. Summer and winter differences in size-frequency distributions of molluscs in full cage, cage control and open control treatments at Shark Alley and North. (Note: Values were too small to plot size-frequency distributions for South.) $\mathrm{n}=$ sample size

Among the 3 locations examined, the greatest feeding intensity occurred at Shark Alley. This may be because it is a natural corridor through which large fish appear to move and was near an aggregation site for Diagramma pictum (Jones \& Ferrell pers. obs.). The greater predation pressure here may explain the fact that this was the only location to exhibit an exclusion effect. Fish feeding is generally more intense around the perimeter zone of the lagoon where mollusc densities are higher (Jones et al. 1991). Therefore, it is the zone in which predators are most likely to have an impact. The feeding intensity at Shark Alley is the highest recorded (cf. Jones et al. 1991), which would suggest that the small effect here ( 2 species out of 10) is the largest that is likely to occur. There is a clear need for information on spatial and temporal changes in predator abundance and feeding pressure, when interpreting these experiments (Choat 1982, St. John et al. 1989, Jones et al. 1991). 
Table 2. Analysis of variance for the effects of exclusion treatments and their controls on the density of teleost feeding scars. Variance for treatment effects (italics) is partitioned among controls and between fish exclusion treatments vs controls ('significant at 0.05 level; $"$ 'significant at 0.01 level; ns: not significant)

\begin{tabular}{|c|c|c|c|c|}
\hline Factor & $\mathrm{df}$ & SS & MS & $F$ \\
\hline Time, A & 3 & 21.1 & 7.1 & $3.3^{\mathrm{ns}}$ \\
\hline Location, B & 2 & 36.4 & 18.2 & $12.4^{\cdots}$ \\
\hline Treatment, C & 2 & 30.9 & 15.4 & $7.0^{\circ}$ \\
\hline Among controls & 1 & 0.3 & & \\
\hline Treatment vs controls & 1 & 30.6 & & \\
\hline Plot, D (BC) & 9 & 13.1 & 1.5 & $9.2 \cdots$ \\
\hline$A \times B$ & 6 & 13.0 & 2.2 & $4.3^{\cdots}$ \\
\hline$A \times C$ & 6 & 9.0 & 1.5 & $3.1^{\bullet}$ \\
\hline Time among controls & 3 & 4.5 & & \\
\hline Time treatment vs control & 3 & 4.5 & & \\
\hline $\mathrm{A} \times \mathrm{D}(\mathrm{BC})$ & 27 & 13.7 & 0.5 & $3.2 \cdots$ \\
\hline $\mathrm{B} \times \mathrm{C}$ & 4 & 8.8 & 2.2 & $1.5^{\mathrm{ns}}$ \\
\hline $\mathrm{A} \times \mathrm{B} \times \mathrm{C}$ & 12 & 5.8 & 0.5 & $1.0^{\mathrm{ns}}$ \\
\hline Residual & 360 & 57.3 & 0.16 & \\
\hline
\end{tabular}

There are few other studies of tropical soft-sediment invertebrate populations, in which the importance of predation has been evaluated experimentally. Keller (1983) found an effect of fish predators on the abundance of the sea urchins Tripneustes ventricosus and Lytechinus variegatus at only 1 of 2 sites examined in the lagoon of Discovery Bay, Jamaica. In a previous study, we found a significant effect of fishexclusion treatments on 3 of 9 molluscs found on the shallow sand flat of One Tree lagoon (Jones et al. 1988). However, we could not excluce the possibility that disturbance and/or interactions among molluscs contributed to the patterns.

The predation effects detected in the present experiment were clearly location- and time-specific. They were also small in magnitude, relative to the observed variation in numbers in space and time. Location and time factors accounted for considerably more variation than treatments (averages: 'Location', 8\%; 'Time', $16 \%$; 'Treatment', $<1 \%$ ). We join others in arguing against making generalisations based on experiments carried out at one site, or in too short a time, or considering too few prey species (Peterson \& Beal 1989). As with competition (see Welden \& Slauson 1986), predation may be intense, but unimportant to the ecology of the prey species.

Examination of the changes in population structure over time indicated that the observed seasonality was a product of summer pulses of recruitment and the winter loss of large individuals. Although species such as Lethrinus nebulosus prefer large prey, there is no evidence that size-biased predation contributes to these patterns for preferred prey such as Umbonium guamensis and Fragum sp. We detected no late

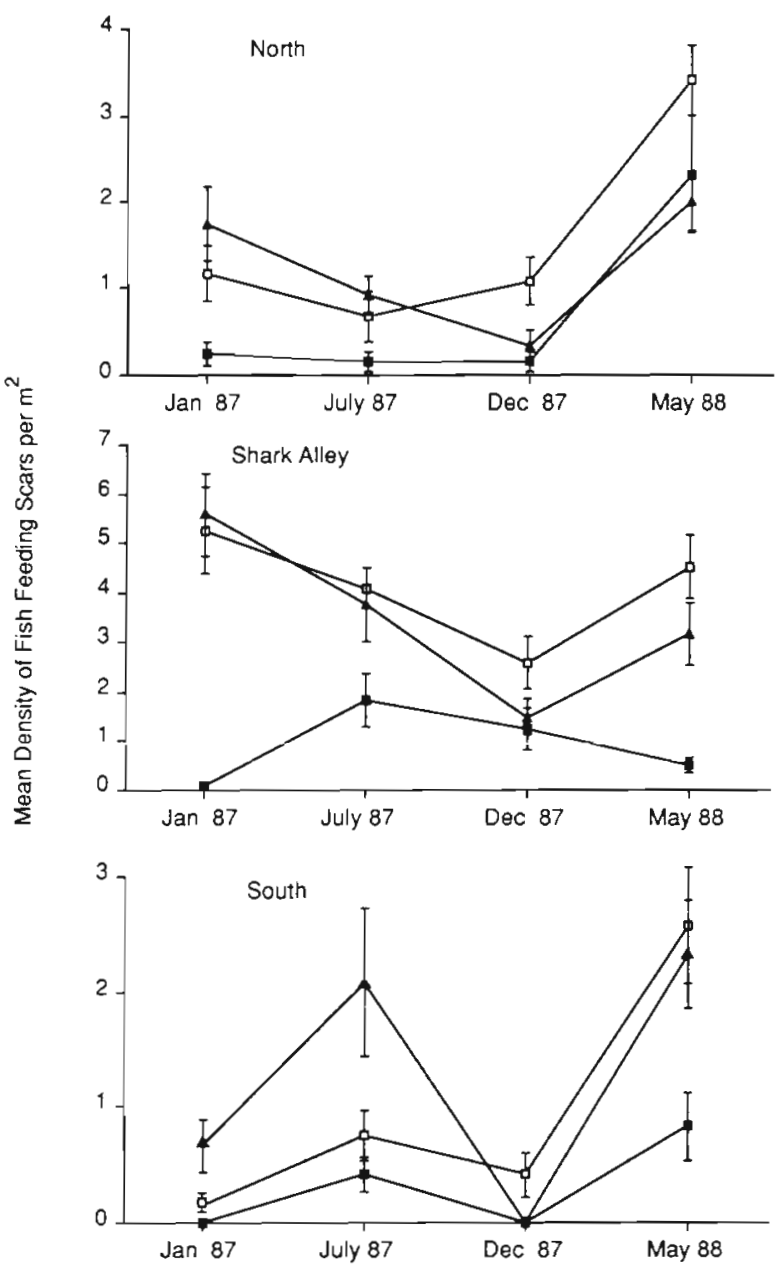

Fig. 11. Temporal changes in mean densities of teleost feeding scars in full cage (一), cage control $(\boldsymbol{\Lambda})$ and open control (미) treatments at North, Shark Alley and South. Error bars = standard errors

Table 3. Estimates of density of fish feeding scars and rate at which artificially made scars became unrecognisable. These are standardised to a daily estimate of feeding scars which in turn allow an estimate of the time to turn over the top $5 \mathrm{~cm}$ of sediment. The area of a single bite was estimated to be a circle $35 \mathrm{~mm}$ in diameter

\begin{tabular}{|lcccc|}
\hline Location & $\begin{array}{c}\text { Mean no. } \\
\text { scars m }\end{array}$ & $\begin{array}{c}\text { Mean time } \\
\text { for all scars } \\
\text { to disappear } \\
\text { (h) }\end{array}$ & $\begin{array}{c}\text { Estimated } \\
\text { no. bites } \\
\mathrm{d}^{-1} \mathrm{~m}^{-2}\end{array}$ & $\begin{array}{c}\text { Days to } \\
\text { turn } \\
\text { over } 1 \mathrm{~m}^{2}\end{array}$ \\
\hline Shark Alley & 4.1 & 27.8 & 3.5 & 293 \\
South & 1.0 & 29.5 & 0.8 & 1283 \\
North & 1.5 & 32.2 & 1.1 & 936 \\
\hline
\end{tabular}

winter increase in predation pressure which could explain the decimation of adult populations at this time.

The potential for predation effects would, however, appear to be considerable, given the effectively annual 


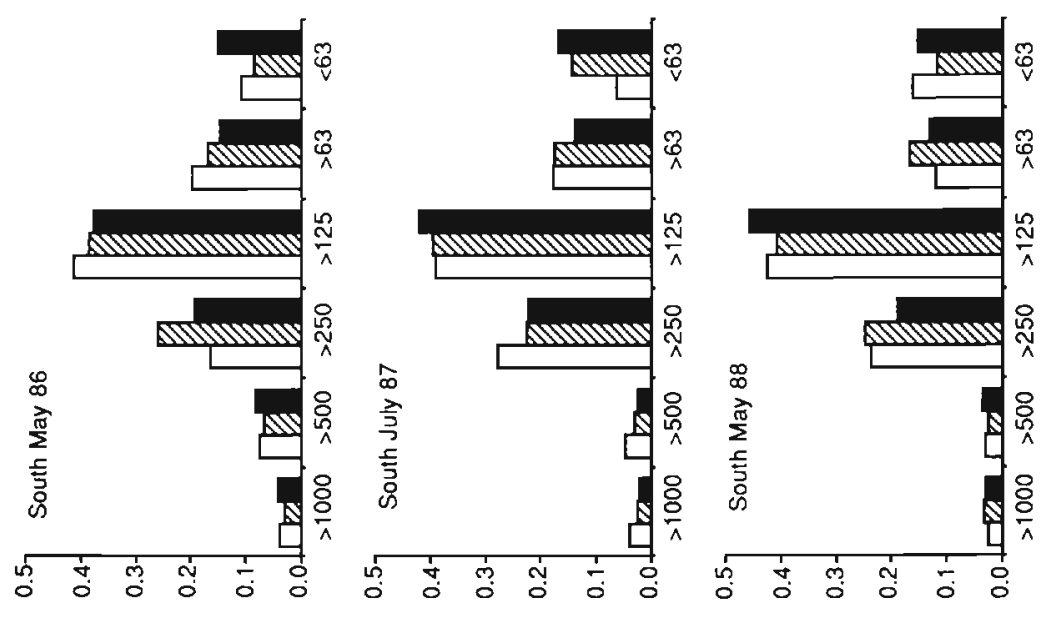

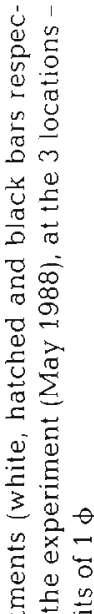
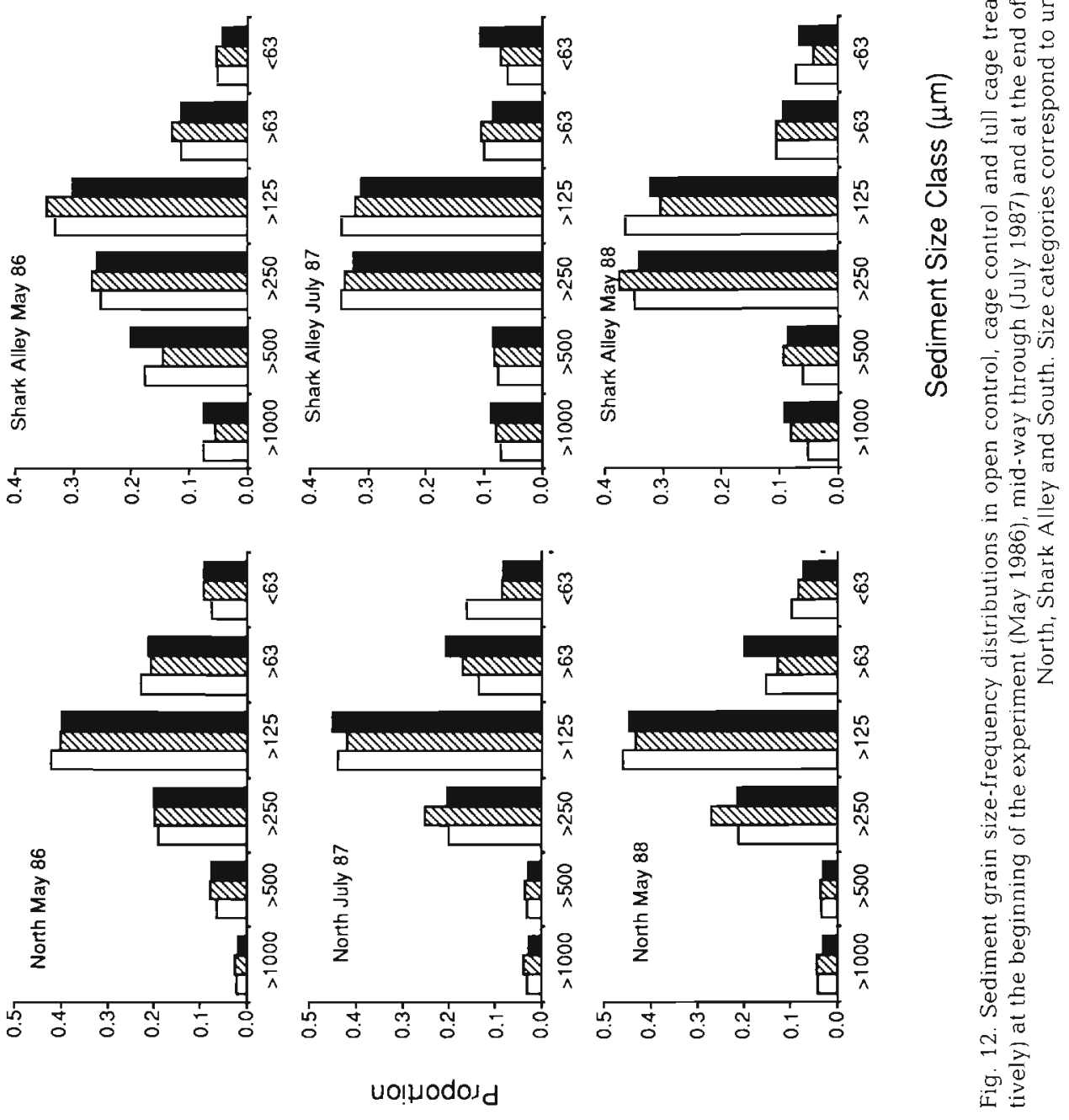
life cycles and the maximum feeding rates observed. At Shark Alley, we conservatively estimate that predators are able to completely turn over the sediments in the course of a year. If they were $100 \%$ efficient in extracting molluscs from the sediment, they would be potentially capable of removing an entire cohort. We assume that the majority of molluscs do not have a refuge in depth, as most are found in the top $5 \mathrm{~cm}$ (Jones et al. 1988). Without data on actual consumption rates of each species, it is difficult to say what proportion of the recruits is eventually consumed by predators. This approach has been used to estimate the potential impact of fish predators on soft-sediment prey (e.g. Alheit 1981, Bennett \& Branch 1990), and in the future may assist in the interpretation of caging experiments.

If the intense feeding pressure does have an important effect on prey numbers, a number of factors may have contributed to our failure to detect this. Failure to detect a significant effect of any factor (to reject the null hypothesis of no effect) may be due to the low power of an experiment caused by small sample size or large sampling variability (Cohen 1988, Peterman 1990). However, in this case treatment effects were detected for a number of species. One has to assume there was sufficient power to detect effects of this magnitude for the others; indeed power analysis for the main treatment effects indicated it is unlikely effects large enough to contribute to the major patterns of change in mean abundance escaped detection.

The most plausible alternative explanation for the lack of detected predation effects lies in the potential mobility of the prey organisms. If these molluscs were so mobile as to move in and out of caged areas during normal movements, predation effects would have been swamped and averaged over a scale that the experiment could not detect (Raffaelli \& Milne 1987. Frid 1989). It has been suggested that mobility is an important factor in structuring benthic communities (Posey 1987). Few studies have examined the movements of prey animals in conjunction with predatorexclusion experiments, and this is particularly difficult for the non-surface-dwelling molluscs we studied here. Movements may be highest for gastropods such as Umbonium guamensis, which can swim several centimeters when disturbed. However, a factor supporting our conclusion that predation is unimportant is the cage size. The $25 \mathrm{~m}^{2}$ area is much greater than cages which have detected effects of predation or disturbance on other soft substrata (e.g. Van Blaricom $1982\left[0.75 \mathrm{~m}^{2}\right.$ ], Federle et al. 1983 [4 $\mathrm{m}^{2}$ ], Keller 1983 [4 $\mathrm{m}^{2}$ ], Quammen $1984 \quad\left[1 \mathrm{~m}^{2}\right.$ ], Raffaelli \& Milne $1987\left[4 \mathrm{~m}^{2}\right]$, Jones et al. $1988\left[16 \mathrm{~m}^{2}\right.$ l, Martin et al. $\left.1989\left[1 \mathrm{~m}^{2}\right]\right)$.
There is a suite of other factors which could account for the dramatic loss of adults during winter. During July 1987, many of the largest Fragum sp. and some other species were found dead or dying on the surface of the sand, at densities of 2 to 3 per $10 \mathrm{~m}^{2}$ (Ferrell \& Jones pers. obs.). These had an extreme gape and would not close their valves when prodded. We also observed many dead shells with tissue still inside, indicating death was recent and not due to fish. This pattern of mortality may simply reflect an annual, semelparous life history. However, cold temperatures may be involved, since both high and low temperatures are known to affect mortality rates in molluscs (Chitramvong et al. 1981, Cranford et al. 1985, Vareille-Morel 1985). Epibenthic predators, such as small fish and predatory gastropods, were not examined. Since these have been found important in other systems (Peterson 1979), they do need to considered in future tropicai studies.

It was hoped that the large mesh size and cage size would reduce cage artifacts which developed over the course of the pilot experiment (Jones et al. 1988). The effects of cages on sediment structure observed in some experiments (e.g. Hulberg \& Oliver 1980, Jones et al. 1988) did not occur in this instance. Some other mechanism must have accounted for the effect of cages on Atys cylindricus, Fragum sp. and Solemya $\mathrm{sp}$. The problem of fish breaching the full cages was clearly a design fault. However, we had clear evidence that although fish did enter some of these cages toward the end of a between-sampling period, there was significantly less feeding than in both types of control areas.

In conclusion, our experiment does not support a model in which fish predation has a major effect on the dynamics of mollusc populations in One Tree lagoon. Although some statistically significant effects were detected, these were small relative to the patterns observed. There are a number of alternative causal explanations, such as physical factors and epibenthic predators, which need to be considered. In future reviews this study must not become a data point supporting the notion that predation pressure is higher in the tropics. We have considerable reservations about making such comparisons based solely on the frequencies at which significant effects are detected along a latitudinal gradient. In each case, the contribution of different types of predators to the overall population changes must be quantified.

Acknowledgements. Special thanks to C. Hayward, L. Howitt, U. Kaly, I. Martin, J. Martin, M. Milicich, M. Norman and $G$. Skilleter for the much needed field assistance. Comments on the manuscript by $N$. Andrew, R. Cole and C. Syms and 2 anonymous reviewers were much appreciated. The 
work was supported by a grant to P.F.S. and G.P.J. from the Australian Marine Science and Technologies Grant Scheme. This is a contribution for the University of Sydney's One Tree Island Field Station.

\section{LITERATURE CITED}

Alheit, J, (1981). Feeding interactions between coral reef fishes and the zoobenthos. In: Gomez, E. D., et al. (eds.) Proc 4th Int. Coral Reef Symp., Manila 2: 545-552

Alheit, J., Scheibel, W. (1982). Benthic harpacticoids as a food source for fish. Mar. Biol. 70: 141-147

Bakus, G. J. (1964). The effects of fish-grazing on invertebrates evolution in shallow tropical waters. Allan Hancock Foundation Publications Occasional Paper, Univ. Southern Calif. Press, Los Angeles, Calitornia 27: 1-29

Bakus, G. J. (1969). Energetics and feeding in shallow marine waters. Int. Rev. gen. exp. Zool. 4: 275-369

Bakus, G. J. (1981). Chemical defense mechanisms on the Great Barrier Reef, Australia. Science 211:497-499

Bakus, G. J. (1983). The role of fishes in the structuring of coral reef communities. Proc. Int. Conf. Mar. Sci. in the Red Sea. Bull. Egyptian Inst. Oceanogr. Fish. 9: 186-192

Bennett, B. A., Branch, G. M. (1990). Relationships between production and consumption of prey species by resident fish in the Bot, a cool temperate South African estuary. Estuar. coast. Shelf Sci. 31: 139-155

Berge, J. A., Valderhaug, V A. (1983). Effect of epibenthic macropredators on community structure in subtidal organically enriched sediments in the inner Oslofjord. Mar. Ecol. Prog. Ser. 11: 15-22

Bertness, M. D. (1981). Predation, physical stress, and the organization o a tropical rocky intertidal hermit crab community. Ecology 62: 411-425

Birtles, A., Arnold, P. (1983). Between the reefs: some patterns of soft substrate epibenthos on the central Great Barrier Reef shelf. In: Baker, J. T., et al. (eds.) Proc. Inaugural Great Barrier Reef Conf., Townsville, p. 159-163

Chitramvong, Y P., Upatham, E. S., Sukhapanth, N. (1981). Effects of some physico-chemical factors on the survival of Bithynia siamensis siamensis, Radix rubiginosa and Indoplanorbis exustus. Malac. Rev. 14: 43-48

Choat, J. H. (1982). Fish feeding and the structure of benthic communities in temperate waters. Ann. Rev. Ecol. Syst. 13 $423-429$

Cohen, J. (1988). Statistical power analysis for the behavioral sciences. Lawrence Erlbaum Associates, New Jersey

Cranford, P. J., Peer, D. L., Gordon, D. C. (1985). Population dynamics and production of Macoma balthica in Cumberland Basin and Shepody Bay, Bay of Fundy. Neth. J. Sea Res. 19: 135-146

Day, R. W. (1977). Two contrasting effects of predation on species richness in coral reef habitats. Mar Biol. 44: 1-5

Day, R.W. (1985). The effects of refuges from predators and competitors on sessile communities on a coral reef. In: Gabrié, C. et al. (eds.) Proc. 5th Int. Coral Reef Symp., Vol. 4. Antenne Museum-EPHE, Moorea, French Polynesia, p. 41-45

Federle, T W., Livingstone, R. J., Meeter, D. A., White, D. C. (1983). Modifications of estuarine sedimentary microbiota by exclusion of epibenthic predators. J. exp. mar. Biol. Ecol. 73: 81-94

Fitz, C. H., Reaka, M. L., Bermingham, E., Wolf, N. G. (1983). Coral recruitment at moderate depths: the influence of grazing. In: Reaka, M. L. (ed.) The ecology of deep and shallow coral reefs. Symp. Ser. Undersea Res. NOA. Undersea Res. Progr., Rockville, p. 89-96
Folk, R. L. (1974). Petrology of sedimentary rocks. Hemphill, Austin

Frid, C. L. J. (1989). The role of recolonization processes in benthic communities, with special reference to the interpretation of predator-induced effects. J. exp. mar Biol. Ecol. 126: 163-171

Gaines, S. D., Lubchenco, J. (1982). A unified approach to marine plant-herbivore interactions. It. Biogeography. Ann. Rev. Ecol. Syst. 13: 11-138

Hatcher, B. G., Johannes, R. E., Robertson, A. I. (1989). Review of research relevant to the conservation of shallow tropical marine ecosystems. Oceanogr. mar. Biol. Ann. Rev. 27: $337-414$

Hulberg, L. W., Oliver, J. S. (1980). Caging manipulations in marine soft-bottom communities: importance of animal interactions or sedimentary modifications. Can. J. Fish. Aquat. Sci. 37: 1130-1139

Jones, A. R. (1984). Sedimentary relationships and community structure of benthic crustacean assemblages of reefassociated sediments at Lizard Island, Great Barrier Reef. Coral Reefs 3: 101-111

Jones, G. P., Ferrell, D. J., Sale, P. F. (1990). Spatial pattern in the abundance and structure of molluscs populations in the soft sediment of a coral reef lagoon. Mar. Ecol. Prog. Ser. 62: 109-120

Jones, G. P., Ferrell, D. J., Sale, P. F. (1991). Fish predation and its impact to the invertebrates of coral reefs and adjacent sediments. In: Sale, P. F. (ed.) The ecology of coral reef fishes. Academic Press, New York, p. 156-179

Jones, G. P., Sale, P. F., Ferrell, D. J (1988). Do large carnivorous fishes affect the ecology of macrofauna in shallow lagoonal sediments? A pilot experiment. In: Choat, J. H. et al. leds.) Proc. 6th Int. Coral Reef Symp., Vol. 2. Sixth International Coral Reef Symposium Executive Committee, Townsville, p. 77-82

Keller, B. D. (1983). Coexistence of sea urchins in seagrass meadows: an experimental analysis of competition and predation. Ecology 64: 1581-1598

Lubchenco, J., Menge, B. A., Garrity, S. D., Lubchenco, P. J., Ashkensas, L. R., Gaines, S. D., Emlet, R., Lucas, J., Strauss, S. (1984). Structure, persistence, and role of consumers in a tropical rocky intertidal community (Taboguilla Island, Bay of Panama). J. exp. mar. Biol. Ecol. 78: $23-73$

Martin, T. H., Wright, R. A., Crowder, L. B. (1989). Nonadditive impact of blue crabs and spot on their prey assemblages. Ecology 70: 1935-1942

McClanahan, T. R., Muthiga, N. A. (1989). Patterns of predation on a sea urchin, Echinometra mathaei (de Blainville), on Kenyan coral reefs. J. exp. mar. Biol. Ecol. 126: 77-94

Menge, B. A., Sutherland, J. P. (1976). Species diversity gradients: synthesis of the roles of predation, competition, and temporal heterogeneity. Am. Nat. 110: 351-369

Neudecker, S. (1977). Transplant experiments to test the effect of fish grazing on coral distribution. In: Taylor, D. L. (ed.) Proc. 3rd Int. Coral Reef Symp. Miami School of Marine and Atmospheric Sciences, Miami, p. 317-323

Neudecker, S. (1979). Effects of grazing and browsing fishes on the zonation of corals in Guam. Ecology 60: 666-672

Parrish, J. D. (1989). Fish communities of interacting shallowwater habitats in tropical oceanic regions. Mar. Ecol. Prog. Ser. 58: 143-160

Peterman, R. M. (1990). Statistical power analysis can improve fisheries research and management. Can. J. Fish. Aquat. Sci. 47: 2-15

Peterson, C. H. (1979). Predation, competitive exclusion, and diversity in the soft-sediment communities of estuaries 
and lagoons. In: Livingstone, R. J (ed.) Ecological processes in coastal and marine systems. Plenum Press, New York, p. 233-264

Peterson, C. H., Beal, B. F. (1989). Bivalve growth and higher order interactions: importance of density, site, and time. Ecology 70: 1390-1404

Posey, M. H. (1986). Influence of relative mobilities on the composition of benthic communities, Mar. Ecol. Prog. Ser. 39: $99-104$

Quammen, M. L. (1984). Predation by shorebirds, fish, and crabs on invertebrates in intertidal mudflats: an experimental test. Ecology 65: 529-537

Raffaelli, D., Milne, H. (1987). An experimental investigation of the effects of shorebird and flatfish predation on estuarine invertebrates. Estuar. coast. Shelf Sci. 24: 1-13

Reaka, M. L. (1985). Interactions between fishes and the motile benthic invertebrate on reefs: the significance of motility vs. defensive adaptations. In: Gabrié, C. et al. (eds.) Proc 5th Int. Coral Reef Symp., Vol. 5. Antenne Museum - EPHE, Moorea, French Polynesia, p. $439-444$

Reise, K (1977). Predation exclusion experiments in an intertidal mudfiat. Helgoländer wiss. Meeresunters. 30: 263-271

Sih, A., Crowley, P., McPeek. M., Petranka, J., Strohmeier, K. (1985). Predation, competition, and prey communities: a review of field experiments. Ann. Rev. Ecol. Syst. 16: 269-311

St. John, J., Jones, G. P., Sale, P. F. (1989). The distribution and abundance of soft-sediment meiofauna and a predatory goby in a coral reef lagoon. Coral Reefs $8: 51-5$ ?

This article was presented by A.J. Underwood, Sydney, Australia
Taylor, J. D. (1971). Reef associated molluscan assemblages in the western Indian Ocean. Symp. zool. Soc. Lond. 28: 501-534

Thrush, S. F. (1986). Community structure on the floor of a sea-lough: are large epibenthic predators important? J. exp. mar. Biol. Ecol. 104: 171-183

Van Blaricom, G. R. (1982). Experimental analysis of structural regulation in a marine sand community exposed to oceanic swell. Ecol. Monogr. 52: 283-305

Vareille-Morel, C. (1985). Resistance of the prosobranch Potamopyrgus jenkinsi (E. A. Smith, 1889) to decreasing temperatures: an experimental study. Annls Limnol. 21 $221-226$

Vermeij, G. J., Veil, J. A. (1978). A latitudinal pattern in bivalve shell gaping. Malacologia 17: 57-61

Welden, C. W., Slauson, W. L. (1986). The intensity of competition versus its importance: an overlooked distinction and some implications. Q. Rev. Biol. 61: 23-44

Wellington, G. M. (1982). Depth zonation of corals in the Gulf of Panama: control and facilitation by resident reef fish. Ecol. Monogr. 52: 223-241

Wilson, W. H. (1991). Competition and predation in marine soft-sediment communities. Ann. Rev. Ecol. Syst. 21. $221-41$

Winer, B. J. (1971). Statistical principles in experimental design. McGraw-Hill, Kogakusha, Tokyo

Wolf, N. G., Bermingham, E. B., Reaka, M. L. (1983). Relationships between fishes and motile benthic invertebrates on coral reefs. In: Reaka, M. L. (ed.) The ecology of deep and shallow coral reefs. Symp. Ser. Undersea Res. NOAA Undersea Res. Progr., Rockville, p. 69-78

Manuscript first received: April 24, 1991

Revised version accepted: December 19,1991 